\title{
TROPICALISMO E BARBÁRIE: RESISTÊNCIA CULTURAL E DITADURA MILITAR NO BRASIL DOS ANOS 1960
}

\author{
TROPICALISMO Y BARBÁRIE: \\ RESISTÊNCIA CULTURAL E DICTADURA MILITAR EN BRASIL EN \\ LOS AÑOS 1960
}

Orlando José Ribeiro de Oliveira

Universidade Estadual do Sudoeste da Bahia

\begin{abstract}
Resumo
A partir dos índices do clima repressivo político-policial no Brasil do final dos anos 1960, enunciados nas letras das canções tropicalistas, identifica-se e analisa-se o caráter engajado-insurrecional do discurso musical produzido pelo chamado Grupo Baiano como mecanismo de enfrentamento político e de resistência cultural à barbárie institucionalizada com a consolidação do projeto de modernização autoritária-conservadora da ditadura militar instalada com o golpe de abril de 1964. Destoando do padrão formal do alinhamento dogmático entre arte e política, expresso na temática nacional-popular da canção engajada do período, o Grupo Baiano mediante a intervenção tropicalista, incorporou o imaginário internacional da juventude - rock n'roll (Beatles, Jimi Hendrix, Bob Dylan), drogas, liberdade sexual e rebeldia à canção urbana, tematizou aspectos da sociedade de consumo (a dimensão mercadológica da música popular) e valorizou a diversidade musical/rítmica brasileira, numa atitude devoradora que retomava o radicalismo da vanguarda antropofágica do Modernismo de 1928.
\end{abstract}

Palavras-chave: Tropicalismo. Resistência Cultural. Barbárie. Ditadura Militar. Brasil.

\section{Resumen}

A partir de los índices del clima represivo político-policial en Brasil a finales de la década de 1960, enunciados en las 
letras de las canciones tropicalistas, se identifica y analiza el carácter comprometido-insurreccional del discurso musical producido por el llamado Grupo Baiano como mecanismo de enfrentamiento político y de resistencia cultural a la barbarie institucionalizada con la consolidación del proyecto de modernización autoritariaconservadora de la dictadura militar instalada con el golpe en abril de 1964. Desentonando del patrón formal de alineamiento dogmático entre el arte y la política, expresado en la temática nacional-popular de la canción implicada con el período, el Grupo Baiano, a través de la intervención tropicalista, incorporó el imaginario internacional de la juventud - rock n'roll (Beatles, Jimi Hendrix, Bob Dylan), drogas, libertad sexual y rebeldía en las canciones urbanas, aspectos temáticos de la sociedad de consumo (la dimensión mercadológica de la música popular) y valorizó la diversidad musical / rítmica brasileña, en una actitud devoradora que retomaba el radicalismo de la vanguardia antropofágica del modernismo en 1928.

Palabra clave: Tropicalismo. Resistencia cultural. Barbarie. Dictadura Militar. Brasil.

\section{Introdução}

Este trabalho discute o caráter engajado-insurrecional do discurso musical tropicalista, produzido pelo então chamado Grupo Baiano (Caetano Veloso, Gilberto Gil, Tom Zé, Gal Costa, José Carlos Capinan, Torquato Neto) no contexto da "relativa hegemonia cultural da esquerda" (SCHWARZ, 1978, p. 62) no sistema da Música Popular Brasileira da época, a partir dos índices do clima repressivo político-policial do Brasil sob o regime da ditadura militar no final dos anos 1960, conforme sua enunciação nas letras das canções tropicalistas.

A intervenção tropicalista ocorrida, no curto período de 1967-1968, é considerada por Coelho (2010, p.133) como "resultado de um movimento estético-musical caracterizado basicamente por uma aliança estratégica e produtiva entre músicos e compositores baianos e intelectuais paulistas"i. Representou, por sua radicalidade crítica, um mecanismo de enfrentamento político e de resistência cultural à barbárie institucionalizada com a consolidação do projeto de modernização autoritária-conservadora da ditadura militar ${ }^{\text {ii }}$ instalada com o golpe de abril de 1964. Rompendo com o padrão formal de alinhamento 
dogmático entre arte e política, expresso pelo viés nacional-popular das canções engajadas da época (canção de protesto), o Grupo Baiano incorporou, em suas obras, o imaginário pop da juventude - rock n'roll (Beatles, Jimi Hendrix, Bob Dylan), drogas, liberdade sexual e rebeldia -, tematizou criticamente aspectos da sociedade de consumo (a dimensão mercadológica da música popular) e valorizou a diversidade musical/rítmica brasileira, numa fatura alegórica ${ }^{i i i}$ e atitude crítica devoradora na retomada do radicalismo antropofágico da vanguarda modernista de 1928.

Até a decretação do AI-5, em dezembro de 1968, a despeito da ditadura militar de direita, a hegemonia da produção cultural de esquerda parecia produzir certo alheamento aos prenúncios de tempos sombrios que se anunciavam. A Música Popular Brasileira - MPB se revelaria, melhor que outras linguagens artísticas, como a expressão mais bem-acabada do 'ensaio geral da socialização da cultura', conforme a formulação precisa de Walnice N. Galvão (1994) para caracterizar a conjuntura nacional no bem-sucedido engajamento da cultura na discussão das grandes questões nacionais que acompanhou o clima revolucionário janguista pré-golpe de 1964.

Se em 1962, em plena era de esperanças ‘janguistas' e reformistas, cultura e projeto político revolucionário formavam um casal perfeito, em 1968 a violência e o radicalismo crescente, que se arraigavam nas cidades brasileiras e na tensão entre o regime militar e a sociedade, forneciam novas bases para se pensar essa relação. (COELHO, 2010, pp. 38-39)

Nesse período, portanto, a MPB assume o papel de meio e mensagem do Brasil (WISNIK, 2004). Herdeira da agitação esquerdista-revolucionáriaiv ${ }^{\text {iv }}$ que floresceu na passagem das décadas de 1950 para 1960, a posição dominante na MPB emergente fazia da "utopia libertária da aliança entre artistas e povo" (RIDENTI, 2003, p. 117) o eixo do discurso engajado, cuja opção pela pureza do nacional-popular evidenciaria o compromisso social do intelectual.

A Moderna Música Popular Brasileira, que depois excluiu o Moderna e entronizou a sigla MPB, se formou, portanto, no refluxo dissolvente das conquistas formais da Bossa Nova, com sua desalienação protagonizada por Carlos Lira, um dos fundadores do CPC da UNE. Logo a seguir, a MPB alimentou-se da criativa produção da emergente geração universitária no pós-64: Edu Lobo, Milton Nascimento, Chico Buarque, Geraldo Vandré e os próprios Caetano Veloso e Gilberto Gil - estes, em início de carreira, ainda na fase prétropicalista, jovens promessas, alinhados ao nacional-popular. Como se pode conferir em Ensaio Geral, Roda, Procissão e Viramundo, composições de Gilberto Gil, e em Coração 

MILITAR NO BRASIL DOS ANOS 1960

Vagabundo, Um dia, É de manhã e Avarandado, de Caetano Veloso, por exemplo, composições que se encaixam na típica forma da canção de protesto, a despeito de certa pegada lírica/romântica de muitas delas.

Abordando os dramas da vida cotidiana de personagens rurais (o 'camponês', o 'vaqueiro', o 'povo' do campo e suas lutas contra a opressão do latifúndio) e urbanos (o 'povo' das favelas, o sambista do morro, o 'operário' explorado), a canção de protesto representou, assim, uma “visão épico-dramática e nacional-popular da história e do Brasil” (WISNIK, 2004, p. 210), difundindo pela música uma suposta 'solidariedade popular romantizada"v , expressa na palavra de ordem "fora da cultura popular não há arte revolucionária", segundo concepção estética formulada pelo CPC da UNE.

Entretanto, como resultado das políticas estatais de superação do subdesenvolvimento iniciadas por Vargas, reorientadas por JK e continuadas pelos militares pós-1964, com seu autoritarismo modernizador e dependente, os processos de industrialização e urbanização transformariam radicalmente o perfil da sociedade brasileira, que passou de rural a urbana, aderindo, incondicionalmente à sociedade de consumo.

Tal conjuntura política, que se radicaliza em 1968 com a escalada crescente dos protestos estudantis e consequente repressão policial, também se manifesta no campo cultural, como resultado não só de processos anteriores de polarização de concepções e interpretações da realidade social, atuantes na produção cultural brasileira (música, literatura, artes plásticas, cinema, teatro, arquitetura etc.), mas também fruto dos acirrados debates sobre identidade nacional e dependência cultural no período, problematizados com o advento da modernização autoritária em curso, deflagrada pela ditadura militar. A polêmica entre correntes ideológicas opostas vai alimentar a produção cultural no momento mesmo de implantação da sociedade de consumo e da indústria cultural no Brasil ${ }^{\mathrm{vi}}$. Este é o momento de intensificação da industrialização dependente e da urbanização. A modernização das telecomunicações, levada a cabo pelos militares, propiciou a consolidação da televisão no Brasil, nova mídia que derrubaria a hegemonia do rádio, inaugurando novas estratégias de indução ao consumo baseadas na imagem, de caráter sobretudo urbano-industrial, formatando, assim, novos produtos culturais (de massas) no Brasil: festivais, telenovelas, disco, mitologia pop etc.

A percepção deste fato, no entanto, disseminou-se apenas entre determinados segmentos da produção cultural contemporânea, como, por exemplo, no caso da música popular, na intervenção 
tropicalista. No agitado ambiente musical de 1968, que gravitava em torno do novo totem, a televisão, o tropicalismo radicalizou em sua ação política no campo musical, produzindo uma verdadeira teoria do Brasil, em que incorporava no seu discurso polifônico, a tradição musical, a jovem guarda, a bossa nova, o rock internacional, a música contemporânea de vanguarda e a “contribuição milionária de todos os erros" (ANDRADE, 2017, p. 23), retomando e assumindo a visão radical e antropofágica do Brasil.

No âmbito da música popular urbana, essa percepção crítica de alguns compositores emergentes da geração pós-bossa nova sobre as contradições da indústria cultural em consolidação no Brasil caracterizaria uma posição alternativa à simplória polarização canção de protesto versus $i \hat{e}-i \hat{e}-i \hat{e}$. Este termo, de caráter pejorativo, se referia à produção de artistas novos, considerada uma música pobre e alienada, uma cópia ingênua e canhestra do rock internacional. Esses novos músicos (e bandas ${ }^{\text {vii }}$ ) alinhavam-se à Jovem Guarda, que não apenas definiu um gênero da música jovem da época, mas também um programa musical de auditório, comandado por Roberto Carlos - o primeiro ídolo pop brasileiro - e transmitido ao vivo nas tardes de domingo pela TV Record, com grande sucesso de público e audiência.

A visão crítica alternativa, representada pela produção do Grupo Baiano ${ }^{\text {viii, }}$, resultaria na agressiva intervenção tropicalista no sistema da indústria do entretenimento (disco, televisão, moda, consumo etc.), deflagrada a partir das canções apresentadas no III Festival da Música Popular Brasileira (TV Record, setembro de 1967) com um impacto surpreendente na audiência daquele período. Os discos individuais Caetano Veloso (Philips, 1968) e Gilberto Gil (Philips, 1968) já antecipavam a alternativa tropicalista de promover uma atualização na música brasileira, aliando música de consumo com música de vanguarda, alta e baixa cultura, formulando, mediante procedimento alegórico e permeado de intertextualidade, uma singular interpretação do Brasil. O artefato tropicalista mais acabado, o disco-manifesto Tropicália ou Panis et Circencis (sic), gravado coletivamente em maio de 1968, constituiu a obra radical de síntese do movimento musical.

As canções tropicalistas resultam de um processo construtivo que agencia imagens que resultam de justaposição de materiais diversos, de elementos díspares, provocando um efeito de obscuridade, de estranheza, como se fosse um sonho. Cena alusiva que alegoriza o Brasil, esta cena desmontada evidencia as aberrações da persistência dos arcaísmos, das deformações no processo de modernização da sociedade, tal como estão explicitados nas interpretações culturais, nas artes, na política, no sistema artístico e cultural (FAVARETTO, 2003, pp. 246-247). 

MILITAR NO BRASIL DOS ANOS 1960

O tropicalismo musical foi só a face mais polêmica e midiaticamente conhecida ${ }^{\text {ix }}$ do movimento que abrangeu o Cinema Novo (Terra em Transe e $O$ Dragão da Maldade contra o Santo Guerreiro de Glauber, Brasil Ano 2000 de Walter Lima Jr. e Macunaíma de Joaquim Pedro de Andrade) e o Cinema Marginal (O Bandido da Luz Vermelha de Rogério Sganzerla, Cara a Cara e O Anjo Nasceu de Júlio Bressane e Blá Blá Blá de Andrea Tonacci), o teatro (O Rei da Vela e Roda Viva de Zé Celso/Teatro Oficina), as artes-plásticas (o ambiente Tropicália de Hélio Oiticica e a arte pop de Rubens Gerchman, Antonio Dias etc.) e a literatura (o romance Panamérica de José Agripino).

\section{Engajamento tropicalista}

Embora frontalmente contrário ao estreito engajamento da canção de protesto, engajamento este fruto da hegemonia do nacional-popular e da concepção utilitarista da arte fomentada pelo CPC, o tropicalismo produziu canções engajadas a seu modo - paródico, irônico, polissêmico, fragmentado, complexo, difícil, enfim, pós-moderno. O engajamento tropicalista - pois, de fato, trata-se disso -, ao rejeitar a subordinação da arte ao campo da política (a canção de protesto como meio de mobilização/conscientização política das massas), reivindicava a especificidade da atuação política do campo das artes.

Com isso, o tropicalismo musical atraiu para si toda a fúria e hostilidade tanto do jovem público universitário - o próprio público-consumidor de seus produtos -, quanto de segmentos conservadores da imprensa e da sociedade brasileira. O clímax da rejeição aos tropicalistas ocorreria durante a apresentação da música É Proibido Proibir por Caetano Veloso acompanhado da banda Os Mutantes, na final da etapa paulista do III Festival Internacional da Canção (TV Globo, 1968) no TUCA em São Paulo, quando a plateia reagindo à performance provocativa dos músicos, vaiou e atirou tomates, ovos e pedaços de pau no palco, motivando o famoso happening de Caetano, em que um discurso nervoso e contundente $^{\mathrm{x}}$ escancarava as limitações estéticas do público.

De maneira geral, o público não percebeu os índices da barbárie em gestação no Brasil daquele momento (enunciados em Lindoneia, Enquanto seu lobo não vem, Marginália II), não decifrou a corrosiva e elaborada crítica ao regime militar e a todo o sistema socioeconômico que lhe dava sustentação (Panis et Circencis, É Proibido Proibir, Divino Maravilhoso, Baby, Eles), nem a 
conclamação explícita dos tropicalistas à resistência e à luta clandestina (Enquanto seu lobo não vem, Divino Maravilhoso), nos sinais e avisos disseminados em suas canções. Favaretto (2003) assinala de forma precisa o alcance da ruptura tropicalista quanto à ideia de engajamento e participação, propostos aqui em outro patamar, diferente do ideário de militância do nacionalpopular cepecista:

As canções tropicalistas produziam também uma ruptura nesse imaginário da participação, operando um deslocamento da arte participante para um tipo de participação focado na ideia de intervenção na estrutura da canção e no gesto, gestos simbólicos, que atingiram tão fortemente quanto a estranheza da composição musical (FAVARETTO, 2003, p.244).

O corpus de análise deste trabalho - conjunto de dados empíricos em forma de letras e músicas - é constituído por doze canções compiladas de cinco discos tropicalistas ${ }^{\mathrm{xi}}$, compostas e gravadas entre 1967 e 1968. Este corpus foi submetido a um levantamento minucioso dos indices textuais que evidenciam, por um lado, a repressão e violência policial e política vigente no estado de barbárie do período referido ${ }^{\mathrm{xii}}$, e, por outro, os sinais indicadores de posições e princípios de resistência e luta defendidos pelos tropicalistas. Além desses, levantou-se ainda os nomeados índices sonoros, expressão que agrupa citações e intertextos musicais na forma de arranjos, acordes e fragmentos, todos eles capazes de revelar os procedimentos alegóricos, as paródias e os pastiches, bem como as montagens e colagens de sons e ruídos, típicos da fatura das canções tropicalistas. Os resultados desse levantamento são apresentados nos Quadros 1 - Índices Textuais: barbárie e resistência na canção tropicalista e 2 - Índices Sonoros: barbárie e resistência na canção tropicalista.

O estado de barbárie que essas canções anunciam, é, assim, evidenciado no Quadro 1 Índices Textuais: barbárie e resistência na canção tropicalista, a seguir, pelo uso reiterado dos termos morte, morrer, matar, sangue, crimes, bomba, guerrilha, fuzil, explodir, canhão, medo, guerra, bala, culpa, aflição, pânico, temer, confusão, faca, punhal, dor, despedaçados, desaparecida, sangrando, policiais vigiando, brutalidade, militar, botas, lama, chamas, escuridão e perigoso dentre outros índices gráficos, que evocam um cenário sombrio e assustador.

Do ponto de vista dos índices de resistência/enfrentamento relativos à posição crítica dos tropicalistas, deve-se destacar, por exemplo, a estrofe 'eu organizo o movimento' da própria canção- 

MILITAR NO BRASIL DOS ANOS 1960

manifesto Tropicália (Caetano Veloso), que se complementa com a atitude de desprendimento e busca de autonomia revelada por 'eu vou / por que não?' de Alegria, Alegria (Caetano Veloso).

\begin{tabular}{|c|c|c|}
\hline \multirow{2}{*}{ CANÇÃOO } & \multicolumn{2}{|c|}{ ÍNDICES TEXTUAIS (palavras, expressões, estrofes) } \\
\hline & De barbárie & De resistência \\
\hline $\begin{array}{l}\text { Tropicália (Caetano Veloso), } \\
\text { Caetano Veloso, LP } 1968\end{array}$ & $\begin{array}{l}\text { morta; bang-bang; sangue; olhos } \\
\text { grandes sobre mim; fossa }\end{array}$ & $\begin{array}{l}\text { eu organizo o movimento / no pulso } \\
\text { esquerdo bangbang / vá pro inferno }\end{array}$ \\
\hline $\begin{array}{l}\text { Alegria, Alegria (Caetano Veloso), } \\
\text { Caetano Veloso, LP } 1968\end{array}$ & crimes; guerrilhas; bomba; fuzil & $\begin{array}{l}\text { contra o vento /eu vou /por entre } \\
\text { fotos e nomes /peito cheio de amo- } \\
\text { res vãos /por que não?/uma canção } \\
\text { me consola /sem livros, sem fuzil } \\
\text { leu quero seguir vivendo }\end{array}$ \\
\hline $\begin{array}{l}\text { Eles } \\
\text { (Caetano Veloso/Gilberto Gil), } \\
\text { Caetano Veloso, LP } 1968\end{array}$ & $\begin{array}{l}\text { creem na existência do bem e do } \\
\text { mal; medo; medo de morrer; } \\
\text { choram; e farinha pouca, meu } \\
\text { pirão primeiro; e não há segred } \\
\text { o; }\end{array}$ & $\begin{array}{l}\text { niilismo, denúncia de convenções } \\
\text { sociais/ familiares }\end{array}$ \\
\hline $\begin{array}{l}\text { Marginália II } \\
\text { (Gilberto Gil/Torquato Neto), } \\
\text { Gilberto Gil, LP } 1968\end{array}$ & $\begin{array}{l}\text { confesso; culpa; pecado; } \\
\text { desesperado; segredo; aflição; } \\
\text { degredo; terceiro mundo; } \\
\text { melancolia; solidão; fim do } \\
\text { mundo; pânico; laço e cadeia; } \\
\text { fome; medo; morte; bomba } \\
\text { explode; temer }\end{array}$ & $\begin{array}{l}\text { ruptura: consciência dos dilemas } \\
\text { nacionais; inventário das riquezas } \\
\text { /mazelas do brasil a ser descorti- } \\
\text { nado/desmoronado; }\end{array}$ \\
\hline $\begin{array}{l}\text { Domingo no Parque (Gilberto Gil), } \\
\text { Gilberto Gil, LP } 1968\end{array}$ & $\begin{array}{l}\text { confusão; brigar; vermelho; ver- } \\
\text { melha; faca; sangue; corpo caído }\end{array}$ & \\
\hline $\begin{array}{l}\text { Panis et Circencis (Caetano } \\
\text { Veloso/ Gilberto Gil), } \\
\text { Tropicália ou Panis et } \\
\text { Circencis, LP } 1968\end{array}$ & $\begin{array}{l}\text { tigres; leões; morrer; punhal; } \\
\text { matar; matei }\end{array}$ & $\begin{array}{l}\text { eu quis cantar / minha canção ilu- } \\
\text { minada de sol / soltei os panos, so- } \\
\text { bre os mastros no ar / soltei os ti- } \\
\text { gres e os leões, nos quintais / man- } \\
\text { dei plantar / folhas de sonho no } \\
\text { jardim do solar / procurar pelo sol }\end{array}$ \\
\hline $\begin{array}{l}\text { Lindoneia (Caetano } \\
\text { Veloso/Gilberto Gil), } \\
\text { Tropicália ou Panis et } \\
\text { Circencis, LP } 1968\end{array}$ & $\begin{array}{l}\text { desaparecida; despedaçados; } \\
\text { atropelados; mortos; policiais } \\
\text { vigiando; sangrando; solidão; } \\
\text { matar; dor }\end{array}$ & $\begin{array}{l}\text { sem que ninguém a visse / no } \\
\text { avesso do espelho / do outro lado } \\
\text { da vida }\end{array}$ \\
\hline
\end{tabular}




\begin{tabular}{|c|c|c|}
\hline $\begin{array}{l}\text { Parque Industrial (Tom Zé), } \\
\text { Tropicália ou Panis et } \\
\text { Circencis, LP } 1968\end{array}$ & $\begin{array}{l}\text { sorriso engarrafado; pecados; } \\
\text { sangue }\end{array}$ & \\
\hline $\begin{array}{l}\text { Geleia Geral } \\
\text { (Gilberto Gil/Torquato Neto), } \\
\text { Tropicália ou Panis et } \\
\text { Circencis, LP } 1968\end{array}$ & $\begin{array}{l}\text { e quem não dança não fala; assiste } \\
\text { a tudo e se cala; superpoder de } \\
\text { paisano; alguém... chora por mim; } \\
\text { brutalidade }\end{array}$ & $\begin{array}{l}\text { poeta desfolha a bandeira / país do } \\
\text { futuro / um carnaval de verdade / } \\
\text { voz do morro }\end{array}$ \\
\hline $\begin{array}{l}\text { Enquanto seu lobo não vem } \\
\text { (Caetano Veloso), } \\
\text { Tropicália ou Panis et Circencis, } \\
\text { LP } 1968\end{array}$ & $\begin{array}{l}\text { militar; estados unidos do brasil; } \\
\text { bombas; bandeiras; botas; lama }\end{array}$ & $\begin{array}{l}\text { vamos passear / floresta escondida } \\
\text { / passear na avenida / passear nas } \\
\text { veredas, no alto / cordilheira sob o } \\
\text { asfalto /por debaixo vamos passear } \\
\text { escondidos / por debaixo }\end{array}$ \\
\hline $\begin{array}{l}\text { É Proibido Proibir } \\
\text { (Caetano Veloso), } \\
\text { Caetano Veloso \& Os Mutantes, } \\
\text { CS } 1968\end{array}$ & $\begin{array}{l}\text { não; dedo; eles estão nos espe- } \\
\text { rando; os automóveis ardem em } \\
\text { chamas; caí; hora adversa; } a \\
\text { morte, a desventura }\end{array}$ & $\begin{array}{l}\text { eu digo não leu digo não ao não /eu } \\
\text { digo é proibido proibir /eles estão } \\
\text { nos esperando /derrubar as } \\
\text { prateleiras /as estantes, as estátuas } \\
\text { las vidraças, louças, livros, sim... /e } \\
\text { eu digo sim / eu digo não ao não /e } \\
\text { eu digo: é proibido proibir /me } \\
\text { guardei }\end{array}$ \\
\hline $\begin{array}{l}\text { Divino Maravilhoso } \\
\text { (Caetano Veloso/Gilberto Gil), } \\
\text { Gal, LP } 1969\end{array}$ & $\begin{array}{l}\text { atenção; esquina; escuridão; } \\
\text { perigoso; temer a morte; o } \\
\text { samba exaltação; as janelas no } \\
\text { alto; o asfalto, o mangue; o } \\
\text { sangue sobre o chão }\end{array}$ & $\begin{array}{l}\text { atenção / precisa ter olhos firmes / } \\
\text { tudo é divino maravilhoso / palavra } \\
\text { de ordem / refrão / é preciso estar } \\
\text { atento e forte / não temos tempo de } \\
\text { temer a morte }\end{array}$ \\
\hline
\end{tabular}

Quadro 1 - Índices Textuais: barbárie e resistência na canção tropicalista

Fonte: Elaborado pelo autor, 2019.

\begin{tabular}{|c|c|}
\hline CANÇÃ̃O & ÍNDICES SONOROS (fragmentos de acordes, citações, ruídos...) \\
\hline $\begin{array}{l}\text { Tropicália (Caetano Veloso), } \\
\text { Caetano Veloso, LP } 1968\end{array}$ & $\begin{array}{l}\text { ruídos / sons de selva, pássaros / bichos / falação impostada } \\
\text { /debochada improvisada; a orquestração mistura naipes eruditos } \\
\text { (sopros e cordas) com instrumentos folclóricos (viola caipira, bongôs, } \\
\text { agogô e triângulo) /anticlímax grandiloquente, canto declamatório; } \\
\text { baião no refrão; citação da pilantragem em 'porém' no comentário da } \\
\text { MPB }\end{array}$ \\
\hline $\begin{array}{l}\text { Alegria, Alegria (Caetano Veloso), } \\
\text { Caetano Veloso, LP } 1968\end{array}$ & dicotomia inaugural: marchinha \& guitarras elétricas \\
\hline $\begin{array}{l}\text { Eles (Caetano Veloso / Gil), } \\
\text { Caetano Veloso, LP } 1968\end{array}$ & $\begin{array}{l}\text { elementos indianos psicodélicos, citação de Within you, without you } \\
\text { (Beatles) / fala de Caetano ao final: "os mutantes são demais!” }\end{array}$ \\
\hline Marginália II (Gil / Torquato Neto), & $\begin{array}{l}\text { metais e sopros frenéticos sobre percussão em ritmo acelerado; } \\
\text { citação do Hino da Independência ('já podeis da pátria filhos...') }\end{array}$ \\
\hline
\end{tabular}



MILITAR NO BRASIL DOS ANOS 1960

\begin{tabular}{|c|c|}
\hline Gilberto Gil, LP 1968 & \\
\hline $\begin{array}{l}\text { Domingo no Parque (Gilberto Gil), } \\
\text { Gilberto Gil, LP } 1968\end{array}$ & $\begin{array}{l}\text { o arranjo edita juntos instrumentos clássicos, tradicionais e elétricos } \\
\text { (orquestra+berimbau+guitarras); ruídos de parque de diversão; } \\
\text { clímax da melodia e coro repetem circularmente (na roda gigante, oi } \\
\text { girando) }\end{array}$ \\
\hline $\begin{array}{l}\text { Panis et Circencis (Caetano Veloso / } \\
\text { Gilberto Gil), } \\
\text { Tropicália ou Panis et Circencis, } \\
\text { LP } 1968\end{array}$ & $\begin{array}{l}\text { vinheta do noticiário Repórter Esso / andamento lento, cadenciado / } \\
\text { "valsa circense" / coro, pandeiros, cordas, teclados / solo intermitente } \\
\text { de trompete cita Penny Lane (Beatles) / voz que morre ( "e mor- } \\
\text { reeerrrrrrrrrr") / interrupção com retardamento para rotação zero / } \\
\text { silêncio / reinício (música eletrônica) / aceleração (música incidental: } \\
\text { rock eletrificado-distorcido, trompete frenético) e interrupção / ruído } \\
\text { de prato quebrado / ruído de vozes e talheres à mesa (jantar) / } \\
\text { orquestração de Danúbio Azul (Strauss) / música concreta crescente / } \\
\text { ruído de vidros quebrados / vórtice / corte }\end{array}$ \\
\hline $\begin{array}{l}\text { Lindoneia (Caetano Veloso/Gilberto } \\
\text { Gil), } \\
\text { Tropicália ou Panis et Circencis, } \\
\text { LP } 1968\end{array}$ & $\begin{array}{l}\text { melismas no naipe de cordas: sonoridade orquestral 'romântica' / } \\
\text { anúncio de bolero / break orquestral / canto suave e triste / citação de } \\
\text { iê-iê-iê ("nas paradas de sucesso") }\end{array}$ \\
\hline $\begin{array}{l}\text { Parque Industrial (Tom Zé), } \\
\text { Tropicália ou Panis et Circencis, } \\
\text { LP } 1968\end{array}$ & $\begin{array}{l}\text { naipe de metais imita banda de coreto / alarido de vozes infantis } \\
\text { (praça em festa) / intervenção cômica de clarinete cita trilha de } \\
\text { chanchada / entonação ufanista / compasso inicial do Hino Nacional } \\
\text { por trombone / falação animada de Gil imita a pilantragem / } \\
\text { entonação paródica de "Braaa-zilê" / vibração da plateia }\end{array}$ \\
\hline $\begin{array}{l}\text { Geleia Geral (Gilberto Gil/ Torquato } \\
\text { Neto), } \\
\text { Tropicália ou Panis et Circencis, } \\
\text { LP } 1968\end{array}$ & $\begin{array}{l}\text { violão percutivo e baixo / efeito sincopado (embolada) / citações: } \\
\text { andamento de choro ( } O \text { Guarani), Sinatra (All the way), batuque de } \\
\text { Escola de Samba / naipe de sopros: acorde da introdução de } \\
\text { Disparada }\end{array}$ \\
\hline $\begin{array}{l}\text { Enquanto seu lobo não vem (Caetano } \\
\text { Veloso), } \\
\text { Tropicália ou Panis et Circencis, LP } \\
1968\end{array}$ & $\begin{array}{l}\text { sequência de percussão, lenta cadência (monotonia): agogô, } \\
\text { woodblock, surdo, violão, baixo / ruptura com metais: trompa, } \\
\text { trompete, flauta, flautim / citações de Dora (Caymmi), A } \\
\text { Internacional Comunista, Hino à Bandeira / rufar de caixas à banda } \\
\text { militar }\end{array}$ \\
\hline $\begin{array}{l}\text { É Proibido Proibir (Caetano Veloso), } \\
\text { Caetano Veloso \& Os Mutantes, CS } \\
1968\end{array}$ & $\begin{array}{l}\text { abertura com guitarras distorcidas, efeitos percussivos, música atonal } \\
\text { / recitativo (Fernando Pessoa) / efeitos, distorções, urros e gritos } \\
\text { [happening: o gringo Johnny Dandurand entra urrando] }\end{array}$ \\
\hline $\begin{array}{l}\text { Divino Maravilhoso (Caetano } \\
\text { Veloso/ Gilberto Gil), } \\
\text { Gal, LP } 1969\end{array}$ & percussão, acordes de guitarra e baixo / coro / gritos \\
\hline
\end{tabular}

Quadro 2 - Índices Sonoros: barbárie e resistência na canção tropicalista

Fonte: Elaborado pelo autor, 2019.

A frase 'uma canção me consola' na mesma Alegria, Alegria de Caetano, revela a tomada de consciência dos limites do campo musical. Embora tais versos evidenciem a defesa da autonomia do campo artístico, na contramão do discurso engajado/militante da época, há que se considerar, no entanto, as ambiguidades e os paradoxos do tropicalismo, ao usar, além da alegoria, a exaltação, 
com sarcasmo carnavalesco e até melancólico, sobre as contradições do Brasil, onde o arcaico e o moderno convivem e se chocam até hoje ( $c f$. a atualidade da dicotomia Casa Grande x Senzala). Em 1968, as "atitudes dos músicos eram estrategicamente planejadas, (...) nos palcos, nos pronunciamentos, nas roupas, nas amizades ou nas aparições em programas de televisão." (COELHO, 2010, p. 112). Enquanto seu lobo não vem, canção de Caetano Veloso, do discomanifesto Tropicália ou Panis et Circencis (LP Philips, 1968), talvez seja a mais engajada canção produzida pelo tropicalismo: tematiza o presente (vamos passear na avenida, uma alusão às passeatas estudantis que ocupavam as ruas das cidades e à crescente escalada de radicalização e violência política/policial) e abole o insistente mito do dia que virá na MMPB (GALVÃO, 1976).

$\mathrm{O}$ teor insurrecional, de conclamação à desobediência civil e de incitamento à clandestinidade da música passou despercebido à época, tanto pelo público em geral - e pelos estudantes, especialmente - quanto pelos militares ${ }^{\text {xiii }}$. Por outro lado, em canções como Divino Maravilhoso (Caetano/Gil), premiada no IV Festival da MPB da TV Record, em 1968, também uma canção engajada, ao modo tropicalista, os autores já chamavam a "atenção para o sangue sobre o chão. As coisas estavam acontecendo, era preciso estar atento e forte, sem tempo de temer a morte..." (RIDENTI, 2003, p. 121). Um pouco antes, no III FIC da TV Globo, a canção É Proibido Proibir, contendo de forma latente forte potencial polêmico, paradoxal e explosivo - cuja letra passeava pelas barricadas estudantis parisienses de maio, mas também afrontava a moral e os costumes tradicionais e conclamava à ação política -, provocou reação agressiva e hostil do público, que não apreendeu o seu recado, em que se misturavam frases das pichações de Paris, iconoclastia, rebeldia juvenil, transgressão, declamação de versos sebastianistas (Fernando Pessoa), happening hippie e música atonal (Os Mutantes), roupas de plástico, colares de dentes etc.

A crescente e recíproca radicalização política (por um lado, protestos estudantis, luta armada clandestina, greves operárias ${ }^{\mathrm{xiv}}$ e por outro, atentados de grupos paramilitares de direita, truculência repressiva policial) que caracterizou a conjuntura nacional em 1968, prenunciando o endurecimento do regime ditatorial, e, portanto, o fim da hegemonia de esquerda na produção cultural brasileira, também está presente nas características do discurso textual das canções tropicalistas: a carnavalização debochada e a tropicalidade do início do movimento (ver/ouvir Tropicália, Alegria, Alegria, Geleia Geral, Parque Industrial) dá lugar aos temas da violência e da marginalidade, que dialogavam com o acirramento dos conflitos

\begin{tabular}{l|l} 
Revista RBBA & Revista Binacional Brasil Argentina
\end{tabular} 


\section{MILITAR NO BRASIL DOS ANOS 1960}

políticos urbanos e da violência repressiva do regime (É Proibido Proibir, Divino Maravilhoso, Questão de Ordem).

Temas como banditismo, armas de fogo, enfrentamentos armados entre policiais e estudantes, desagregação de valores da classe média brasileira, grupos marginalizados da sociedade, entre outros, passam a fazer parte do universo temático das canções tropicalistas a partir da segunda metade de 1968. Canções como Enquanto seu lobo não vem (Caetano Veloso), Divino Maravilhoso (Caetano veloso e Gilberto Gil), É proibido proibir (Caetano Veloso), Marginália II (Torquato Neto e Gilberto Gil) ou Deus vos salve esta casa santa (Torquato Neto e Caetano Veloso) eram emblemáticas para esse momento de radicalização. São canções que tratam de 'bombas' e de 'botas', de não ter tempo para 'temer a morte', das pichações dos jovens de maio de 1968 em Paris, de 'pânico e glória' e de 'laço e cadeia'.(COELHO, 2010, p. 116)

\section{Conclusões}

Se estas, e outras canções, explicitam um protagonismo consciente e autônomo ( 'sem livro e sem fuzil' em Alegria, Alegria, 1967), há que se destacar também o aspecto disruptivo e alegórico da consciência dos dilemas e mazelas nacionais explicitadas em canções como Marginália II (1967), Geleia Geral (1967) e Parque Industrial (1967); o niilismo e a denúncia das convenções sociais de um Brasil familiar, retrógrado e conservador em Panis et Circencis (1967), Eles (1967), Ele falava nisso todo dia (1967) e até a incitação à rebeldia e à clandestinidade em Enquanto seu lobo não vem (1967), É Proibido Proibir (1968) e Divino Maravilhoso (1968). Dada a complexidade da canção tropicalista (em que vanguarda e consumo, arte e mercadoria se fundem), há nela um convite implícito para uma atitude de decifração pelo ouvinte, com recusa à audição passiva. Ademais, ao explorar criativamente a exposição espetacular promovida pela media televisiva, o Tropicalismo, em suas obras, realizou de maneira radical uma

(...) crítica à sociedade de consumo misturada à crítica da moral, dos costumes, dos valores pequeno-burgueses, crítica das posições políticas consagradas - a direita e a esquerda -, a utilização de resíduos culturais populares e eruditos, (...) uma mistura aparentemente caótica e, na verdade, muito bem construída (FAVARETTO, 2003, p. 245).

Como afirma Coelho (2010, p. 112), "a fidelidade a uma ideia salutar do novo como valor popular e de consumo" foi a maior contribuição do tropicalismo musical à produção cultural brasileira. Para o autor, os tropicalistas

Revista RBBA $\mid$ Revista Binacional Brasil Argentina 
(...) visavam fundamentalmente ao contato com uma nova concepção de popular na música e na cultura brasileira. Não mais o popular ligado às 'massas revolucionárias', mas à nova indústria cultural - paradas de sucesso, capas de revista coloridas, programas de televisão, textos de Quentin Fiore e de Marshall McLuhan, pastiche, design industrial, usos do kitsch e experimentação (COELHO, 2010, p. 113).

Ao ocupar o olho do ciclone que significou o ano de 1968 na conjuntura brasileira, o tropicalismo musical produziu elaborados artefatos musicais nas engrenagens da indústria cultural - "Música é para vender, e é batata: não adianta, disco é feito prá vender, então tem que vender, senão não presta”, afirmava Torquato Neto em entrevista à Rádio Cultura (RS), em novembro de 1968 (O GLOBO, 2014).

O tropicalismo sempre exigiu uma escuta apurada do público consumidor, por se tratar de arte "política e difícil”, exigindo uma profunda transformação não apenas do público, mas também da crítica $^{\mathrm{xv}}$, embora estivesse submetido, por conta da superexposição midiática (TV, rádio, jornais e revistas $)^{\mathrm{xvi}}$, a interpretações equivocadas, díspares, preconceituosas e reacionárias, mesmo. Suscitou enorme polêmica, não apenas no meio musical, despertando iras extremadas que foram dos boatos, das intrigas, das vaias às hostilidades explícitas, às agressões e aos ataques reais.

A reação ao tropicalismo incluiu desde cartas-denúncias de associações de mulheres católicas do interior paulista à TV Tupi - transmissora do provocativo programa Divino Maravilhoso, já no final do movimento, invasões, bombas, destruição de cenário, sequestro e espancamento de atores da peça Roda Viva, do Teatro Oficina, em São Paulo e Porto Alegre, às delações e ameaças que resultaram na proibição do show de Caetano, Gil e Os Mutantes na Boate Sucata, no Rio de Janeiro, cujo cenário trazia o estandarte Seja Marginal Seja Herói, homenagem do artista plástico Hélio Oiticica ao bandido Cara de Cavalo, morto pela polícia carioca, além da suspensão do programa Divino Maravilhoso e da própria prisão, e posterior exílio, de Caetano Veloso e Gilberto Gil.

Em outra perspectiva, o tropicalismo musical, enquanto movimento estético, a exemplo de outros tantos movimentos artísticos e culturais do Modernismo no século $\mathrm{XX}^{\mathrm{xvii}}$, como assinalam diversos autores, se desenvolveu em duas fases distintas, complementares e conjugadas. A primeira fase, que foi de meados de 1967 a meados de 1968, se caracterizou pelo projeto estético, produzindo modificações e inovações na linguagem e no formato da canção popular urbana brasileira, em que a atitude iconoclasta e demolidora, carnavalizante, 

MILITAR NO BRASIL DOS ANOS 1960

alegórica e animada contrastava com a atmosfera sisuda e repressiva daqueles tempos, o que acentuava seu aspecto revolucionário. Seguiu-se uma segunda fase (segunda metade do ano de 1968), mais curta, tumultuada e abruptamente interrompida (logo após o AI-5, com a prisão de Caetano e Gil), que consistiu no projeto ideológico em que o pensamento tropicalista e sua visão da época assumiram sua face mais sombria e politizada, levando a experimentação estética e a provocação política a um limite perigoso e insuportável - ver as canções É Proibido Proibir de Caetano e Questão de Ordem de Gil, o show da Boate Sucata e o próprio programa de televisão, Divino Maravilhoso. Em termos, o projeto estético já continha, em latência, o projeto ideológico, este mais radical do que a crítica da linguagem da primeira fase (ver Enquanto seu lobo não vem, Panis et Circencis e Marginália II). Nessa chave analítica, baseada em Lafetá (2000), distingue-se o projeto estético, com suas obras alegres, irreverentes e bem-humoradas, do projeto ideológico, que produziu obras mais experimentais, transgressivas e politicamente provocativas, em atitude de resistência cultural à barbárie que se apossava do Estado no Brasil.

\section{Referências}

ANDRADE, O. de. Manifesto Antropófago e outros. São Paulo: Penguin Classics Companhia das Letras, 2017.

ANDRADE, P. Pássaro de fogo. Rascunho. 2014. Disponível em: http://rascunho.com.br/passaro-de-fogo/. Acesso em 15 de mar. de 2019.

ARAÚJO DUARTE, A. M. S. de; SALOMÃO, W. (Orgs.). Os Últimos Dias de Paupéria (do lado de dentro) Torquato Neto. 2 ed. São Paulo: Max Limonad, 1982.

CALADO, C. Tropicália: a história de uma revolução musical. São Paulo: Ed. 34, 1997.

CAMPOS, A. de. O Balanço da Bossa e Outras Bossas. 2 ed. São Paulo: São Paulo: Perspectiva, 1974.

COELHO, F. Eu Brasileiro, Confesso Minha Culpa e Meu Pecado: cultura marginal no Brasil das décadas de 1960 e 1970. Rio de Janeiro: Civilização Brasileira, 2010.

COSTA, G. Gal Costa. São Paulo: Philips, 1969. Disco sonoro, 39’ 34”.

DUARTE, P S.; NAVES, S. C. (Orgs.). Do Samba-Canção à Tropicália. Rio de Janeiro: Relume Dumará; FAPERJ, 2003. 
DUARTE, P. Tropicália ou Panis et Circencis. Rio de Janeiro: Cobogó, 2018. Coleção O livro do disco.

DUNN, C. Brutalidade Jardim: a Tropicália e o surgimento da contracultura brasileira. São Paulo: Unesp, 2001.

FAVARETTO, C. Tropicália alegoria alegria. $3^{\text {a }}$ edição. São Paulo: Ateliê, 2000.

Tropicália: política e cultura. In: DUARTE, Paulo Sérgio; NAVES, Santuza Cambraia (Orgs.). Do Samba-Canção à Tropicália. Rio de Janeiro: Relume Dumará; FAPERJ, 2003. pp. 242-247.

GALVÃO, W. N. Saco de Gatos: ensaios críticos. São Paulo: Duas Cidades, 1976. . As Falas, os silêncios (literatura e imediações: 1964-1988). In: SCHWARTZ, Jorge; SOSNOWKI, Saul. (Orgs.). Brasil: o Trânsito da Memória. São Paulo: EDUSP, 1994.

GIL, G. Gilberto Gil. São Paulo: Philips, 1968. Disco sonoro, 30’ 57’’

LAFETÁ, J. L. 1930: a Crítica e o Modernismo. São Paulo: Duas Cidades; Ed. 34, 2000.

NAPOLITANO, M. Cultura Brasileira: utopia e massificação (1950-1980). 2 ed. São Paulo: Contexto, 2004.

Seguindo a Canção: engajamento político e indústria cultural na MPB (19591969). São Paulo, Annablume, 2001.

NAVES, S. C. Da Bossa Nova à Tropicália. Rio de Janeiro: Jorge Zahar, 2001.

O GLOBO. Encontrada gravação inédita com único registro de voz de Torquato Neto. Disponível em https://oglobo.globo.com/cultura/musica/encontrada-gravacao-inedita-comunico-registro-de-voz-de-torquato-neto-14069434. Acesso em 28 de set. 2014.

OLIVEIRA, O. "Desejo e Repressão em 1968: sobre uma canção tropicalista". In: Seminário de Teoria e História Literária, 5, 2009, Vitória da Conquista. Anais... Vitória da Conquista: UESB, 2009.

OS MUTANTES. Os Mutantes. São Paulo: Polydor, 1968. Disco Sonoro, 35' 59”.

PAIANO, E. Tropicalismo: bananas ao vento no coração do Brasil. São Paulo: Scipione, 1996.

RIDENTI, M. "Revolução Brasileira na Canção Popular". In: NAVES, S. C.; DUARTE, P. S. (Orgs.). Do Samba Canção à Tropicália. Rio de Janeiro: Relume Dumará/FAPERJ, 2003.

SANCHES, P. A. Tropicalismo: decadência bonita do samba. São Paulo: Boitempo, 2000.

SCHWARZ, R. "Cultura e Política, 1964-1969: alguns esquemas". In: O Pai de Família e Outros Estudos. Rio de Janeiro: Paz e Terra, 1978. pp. 61-92.

VASCONCELOS, G. Música Popular: de olho na fresta. Rio de Janeiro: Graal, 1977. 
VElOSO, C.; GIL, G.; COSTA, G.; LEÃO, N.; MUTANTES; TOM ZÉ. Tropicália ou Panis et Circencis. São Paulo: Philips, 1968. Disco sonoro, 37' 20”'.

VELOSO, C.; Os Mutantes. É Proibido Proibir/Ambiente de Festival. São Paulo: Philips, 1968. Disco sonoro, 15' 55".

Caetano Veloso. São Paulo: Philips, 1968. Disco sonoro, 36’ 27’”.

WISNIK, J. M. Sem Receita: ensaios e canções. São Paulo: Publifolha, 2004.

\title{
Notas
}

\begin{abstract}
i Além dos "intelectuais", deve-se acrescentar, " e músicos paulistas": os garotos da banda Os Mutantes, além dos músicos de vanguarda, maestros e arranjadores Rogério Duprat, Júlio Medaglia, Damiano Cozella e Sandino Hohagen.

ii A rigor, o golpe militar que derrubou o presidente João Goulart em 1 de abril de 1964 implantou no Brasil uma ditadura civil-militar, levando-se em conta o apoio e a adesão de expressivos setores conservadores da sociedade civil brasileira, como as classes médias urbanas, boa parte do empresariado e dos latifundiários, além de segmentos reacionários da igreja católica à conspiração golpista das Forças Armadas, com apoio logístico explícito, inclusivo financeiro, dos Estados Unidos, desde as eleições de 1962.

iii O procedimento alegórico foi utilizado por outras linguagens artísticas do mesmo período, a exemplo de filmes do Cinema Novo (Terra em Transe, de Glauber Rocha) e peças de teatro (O Rei da Vela, de Oswald de Andrade, e Roda Viva, de Chico Buarque, ambas dirigidas por Zé Celso Martinez do Teatro Oficina).

${ }^{\text {iv }}$ Ligas Camponesas no Nordeste, CPC da UNE, Cinema Novo, Teatro de Arena, Teatro Oficina, Movimento Popular de Cultura (PE), Alfabetização Popular (método Paulo Freire) são alguns ícones da ebulição política, social e cultural que caracterizou o período do Governo reformista de João Goulart, quando artistas e intelectuais de esquerda acreditavam na possibilidade de uma revolução socialista no Brasil. Daí a frustração com o golpe.

v O componente romântico dessa concepção resultaria em uma "fetichização do povo como entidade histórica" (NETTO apud VASCONCELOS, 1977, P. 42).

vi Como afirma COELHO (2010, p. 89): "A partir de 1965, a forte ligação entre música-televisão-idolatria popular nos fornece os primeiros ídolos formados no bojo da cultura de massas. Roberto Carlos e Chico Buarque eram verdadeiras 'vedetes', ao lado de Caetano Veloso e Elis Regina. (...) O tropicalismo, a canção de protesto (gerando uma ainda jovem MPB) e a jovem guarda eram como trincheiras: aqueles que pertenciam a um lado não poderiam frequentar o outro."

vii Dentre as bandas e grupos vocais que se destacaram no gênero Jovem Guarda, encontram-se Os Incríveis, The Fevers, Renato e seus Blue Caps, Golden Boys, Trio Esperança e outros.

viii Além dos baianos Caetano, Gil, Tom Zé, Gal, Capinan e Rogério Duarte, o grupo reunia o piauiense Torquato Neto e, depois, já tropicalistas, a capixaba Nara Leão, o carioca Jorge Bem, além dos garotos paulistas da banda Os Mutantes (Arnaldo Baptista, Sérgio Dias e Rita Lee), contando com a colaboração vanguardista do maestro paulista Rogério Duprat.

${ }^{\text {ix }}$ A despeito do ruído midiático provocado - e que fazia parte do show, sob o comando empresarial de Guilherme Araújo - o tropicalismo musical atuou na esfera comportamental, incorporando as novas mídias no processo de produção da música brasileira e refletiu sobre esta questão, aproveitando-se de todas as frestas para passar o seu recado: festivais, debates, happenings, programas de auditório, imprensa etc. A propósito, a fala do maestro Rogério Duprat no (suposto) roteiro de filme veiculado na contracapa do disco-manifesto Tropicália ou Panis et Circenses (Phillips, 1968), alerta para as implicações da indústria cultural e da cultura de massas: “(...) vocês, mal saídos do borralho, vocês baianos, (...) Como receberão a notícia de que o disco é feito para vender?".

x "Mas é isso que é a juventude que diz que quer tomar o poder? ... vão sempre, sempre, matar amanhã o velhote inimigo que morreu ontem! Vocês não estão entendendo nada, nada, nada, absolutamente nada ... se vocês, em política, forem como são em estética, estamos feitos!" (VELOSO, 1968).

${ }^{x i}$ Estes títulos encontram-se devidamente arrolados nas referências deste artigo.
\end{abstract}

\begin{tabular}{l|l} 
Revista RBBA & Revista Binacional Brasil Argentina
\end{tabular} 
xii Deve-se atentar para o fato de que apenas em dezembro de 1968, com o Ato Institucional no 5 , é que se inicia o período mais bárbaro, violento e letal da ditadura militar no país, conhecido como os Anos de Chumbo.

xiii Além de não ser das músicas mais veiculadas e populares do disco, na ocasião do seu lançamento ainda não se fazia sentir a ação violenta da Censura neste campo, situação que mudaria, radicalmente, a partir de dezembro daquele ano, com a edição do AI-5.

xiv Dentre os eventos significativos, do lado da contestação, estão a Passeata dos Cem Mil no Rio de Janeiro; o surgimento dos grupos políticos clandestinos que iniciam nesse ano as "expropriações" (assaltos a bancos) para financiamento da luta armada contra a ditadura; os movimentos grevistas operários em Osasco (SP) e Contagem (MG), e do lado da situação, a invasão policial do Restaurante Calabouço e o assassinato do secundarista Édson Luís no Rio de Janeiro; a ação terrorista de direita com os atentados à bomba pelo Comando de Caça aos Comunistas - CCC, em São Paulo e no Rio de Janeiro; a guerra da Rua Maria Antônia, em São Paulo, entre estudantes da FFCL-USP e da Universidade Mackenzie, com participação da Sociedade Brasileira de Defesa da Tradição, Família e Propriedade - TFP e do Comando de Caça aos Comunistas - CCC, a Sexta-feira Sangrenta no Rio de Janeiro, quando a ação policial-militar prendeu e reprimiu violentamente estudantes nas dependências universitárias em Botafogo, a prisão de milhares de estudantes no XXX Congresso da UNE, em Ibiúna, interior de São Paulo etc.

xv No calor da hora, os poetas concretos paulistas, Augusto de Campos, Haroldo de Campos e Décio Pignatari, foram os primeiros (e únicos) acadêmicos "sérios" a reconhecer e valorizar o significado e a importância da radical intervenção tropicalista no sistema da produção cultural brasileira. Augusto de Campos publicou, ainda em 1968, o livro Balanço da Bossa e outras bossas, em que reúne material crítico-analítico sobre a produção do Grupo Baiano.

xvi Deve-se destacar e reconhecer a bem-sucedida estratégia mercadológica do empresário Guilherme Araújo, que sempre manteve os músicos tropicalistas sob os holofotes da mídia, possuindo um faro sensível e certeiro para a ocupação de espaços e momentos propícios para a divulgação do artefato musical do Grupo Baiano, a despeito dos boatos e intrigas sensacionalistas, dos ataques e agressões de que ambos foram objeto.

xvii Há, inclusive, autores que veem na intervenção tropicalista a última manifestação antropofágica do modernismo brasileiro.

\author{
Sobre o autor \\ Orlando José Ribeiro de Oliveira é Professor de \\ Antropologia e Cultura Brasileira da Universidade \\ Estadual do Sudoeste da Bahia, pesquisador-colaborador \\ do Grupo de Pesquisa Cultura, Ambiente e Sociedade: \\ Linguagem e Design Social - CASLIDS (CNPq-UESB). É \\ Doutor em Ciências Sociais (UFBA, 2017) e Mestre em \\ Desenvolvimento Sustentável - Política e Gestão \\ Ambiental (UnB, 2009). Especialista em Ciências Sociais \\ (UFBA, 1981) e em Ciência da Computação (UESB, \\ 1997), sendo Graduado em Arquitetura (Universidade \\ Federal da Bahia, 1977). \\ Endereço eletrônico: orlando.oliveira@uesb.edu.br
}

